\title{
PENERAPAN MODEL PEMBELAJARAN KOOPERATIF TIPE ROUND TABLE DAPAT MENINGKATKAN HASIL BELAJAR PADA POKOK BAHASAN ARITMATIKA SOSIAL DI KELAS VII 8 SMP NEGERI 10 PEKANBARU
}

(Application of Cooperative Learning Model of Round Table Type in Increasing the Results of Learning in the Subject of Social Aritmatics in Class VII 8 Negeri 10 Pekanbaru)

\section{Oleh: Yulmaliza*)}

*) Guru Matematika SMP Negeri 10 Pekanbaru

\begin{abstract}
Learning is essentially a process of interaction with all situations around individuals. Learning activities are the most basic activities in the whole process of education in schools. The success of educational attainment in schools depends on the learning process that students experience as students. Teachers as educators who are directly involved in the implementation of learning in charge of creating learning conditions that can make learners learn optimally to get a satisfactory learning outcomes.The learning process can be done in school, at home, or in the place of study guidance. For learning in school, learners are faced with a number of subjects, one of which is the subject of mathematics. Learning can be viewed as a process directed to the goals and processes of doing through various experiences. Learning is also a process of seeing, observing, and understanding things. Mathematics is one of the subjects received by students in junior high.Mathematics is a science that studies about the material, natural phenomena and mechanisms that occur therein. More simply can be said that math is closely related to daily life. What we experience, what we do, why it happens and why. Subjects in the subject of mathematics is not only a calculation, but also the ability of learners to understand the concept to link learning with daily life. One of the subjects of mathematics in the form of conceptual and calculation or theoretical understanding is social arithmetic. Based on the research results obtained the value of the first cycle, the second cycle daan third cycle in a row $81.85 \%, 84.50 \%$ and $87.43 \%$.
\end{abstract}

Kata Kunci : Cooperative Model, Round Table

\section{PENDAHULUAN}

Belajar pada hakikatnya adalah proses interaksi terhadap semua situasi yang ada di sekitar individu. Belajar dapat dipandang sebagai proses diarahkan kepada tujuan dan proses berbuat melalui berbagai pengalaman. Belajar juga merupakan proses melihat, mengamati, dan memahami sesuatu (Sudjana, 2001). Kegiatan belajar merupakan kegiatan yang paling pokok dalam keseluruhan proses pendidikan di sekolah. Keberhasilan pencapaian tujuan pendidikan disekolah banyak bergantung pada proses belajar yang dialami peserta didik sebagai anak didik. Guru sebagai pendidik yang terlibat langsung dalam pelaksanaan pembelajaran bertugas menciptakan kondisi belajar yang dapat membuat peserta didik belajar dengan optimal untuk mendapatkan hasil belajar yang memuaskan (Slameto, 2003).Dalam proses pembelajaran terdapat dua kegiatan yang saling berinteraksi, yaitu kegiatan belajar dan kegiatan mengajar. Belajar merupakan kegiatan aktif peserta didik dalam membangun makna atau pemahaman. Keaktifan peserta didik dalam menjalani kegiatan pembelajaran merupakan salah satu kunci keberhasilan untuk meningkatkan hasil belajar. Hasil belajar yang optimal merupakan tujuan utama yang ingin dicapai dalam proses pembelajaran. Untuk mengoptimalkan hasil belajar peserta didik diperlukan metode dan model pembelajaran yang 
sesuai dengan materi ajar (Syaiful Bahri Djamarah dan Aswan Zain 2006).Dimyati dan Mudjiono (2010) menyatakan bahwa untuk meningkatkan proses belajar peserta didik, guru harus bisa memilih dan menerapkan cara pembelajaran yang tepat. Apabila guru berhasil menciptakan suasana yang menyebabkan peserta didik termotivasi aktif dalam belajar, maka memungkinkan terjadinya peningkatan prestasi belajar. Proses pembelajaran dapat dilakukan di sekolah, di rumah, ataupun di tempat bimbingan-bimbingan belajar. Untuk pembelajaran di sekolah, peserta didik dihadapkan pada sejumlah mata pelajaran, salah satunya mata pelajaran matematika.Matematika adalah salah satu mata pelajaran yang diterima oleh peserta didik di SMP. Matematika merupakan ilmu yang mempelajari tentang materi, fenomena alam dan mekanisme yang terjadi didalamnya. Lebih sederhananya dapat dikatakan bahwa matematika erat kaitannya dengan kehidupan sehari-hari. Apa yang kita alami, apa yang kita lakukan, kenapa hal itu terjadi dan mengapa demikian. Pokok bahasan dalam mata pelajaran matematika sifatnya tidak hanya perhitungan, tetapi dibutuhkan juga kemampuan peserta didik dalam memahamai konsep untuk mengaitkan pembelajaran dengan kehidupan sehari-hari.Salah satu materi pelajaran matematika yang berupa pemahaman konsep dan hitungan atau teoritis adalah aritmatika sosial.Aritmatika sosial adalah salah satupokok bahasan dalam mata pelajaran matematikayang belum mencapai Kriteria Ketuntasan Minimum (KKM).Berdasarkan pengamatan di kelas VII 8 SMP Negeri 10 Pekanbaru, rata-rata nilai ulangan harian peserta didikpada pokok bahasan aritmatika sosial tahun ajaran 2014/2015 masih rendah.Nilai rata-rata ulangan harian peserta didik belum mencapai KKM. Masih banyaknya peserta didik yang belum mencapai KKMdisebabkan karena kurang aktifnya peserta didik dalam kegiatan pembelajaran. Hal ini dikarenakan pembelajaran yang ada masih berpusat pada guru dan peserta didik hanya mendengarkan penjelasan dari guru sajasehingga peserta didik tidak terlibat aktif dan tidak termotivasi dalam proses pembelajaran.Lebih lanjut ditambahkan, apabila guru memberikan soal latihan dan peserta didik diminta maju menyelesaikannya, peserta didik yang sering maju hanya peserta didik-peserta didik tertentu saja sehingga tidak semua peserta didik terlibat dan ikut berpartisipasi aktif dalam proses pembelajaran. Hal inilah yang menyebabkan materi pelajaran tidak dapat dipahami peserta didik secara utuh sehingga berdampak pada prestasi belajar yang dapat dilihat pada rendahnya nilai ulangan harian peserta didik. Aktivitas merupakan prinsip atau azas penting dalam belajar mengajar(Sardiman, 2009). Peserta didik secara aktif menggunakan otak, baik untuk menemukan ide pokok dari materi pembelajaran, memecahkan persoalan dan mengaplikasikan yang dipelajari ke dalam persoalan dalam kehidupan nyata. Keaktifan peserta didik menjadikan prosespembelajaran menjadi aktivitas bermakna yakni kebebasan untuk melakukan yang terbaik dari yang dia bisa, sehingga peserta didik lebih aktif, kreatif dan mandiri dalam kegiatan belajarmengajar. Peneliti menerapkan model pembelajaran Round Table untuk mengatasi masalah kurang aktifnya belajar peserta didik pada pokok bahasan aritmatika sosial.

\section{METODE PENELITIAN}

Penelitian ini merupakan penelitian tindakan (action research), karena penelitian ini dilakukan untuk memecahkan masalah pelajaran di kelas. Penelitian ini juga termasuk penelitian deskriptif, sebab menggambarkan bagaimana suatu tekhnik pembelajaran diterapkan dan bagaimana hasil yang diinginkan dapai dicapai. Tempat penelitian adalah tempat yang digunakan dalam melakukan penelitian untuk memperoleh data yang diinginkan. Penelitian ini bertempat di SMP Negeri 10 Pekanbaru. Waktu penelitian adalah waktu berlangsungnya penelitian atau saat penelitian ini berlangsung. Penelitian ini dilaksanakan pada awal bulan Februari sampai pertengahan bulan Maret 
2015.Subyek penelitian adalah peserta didik kelas VII 8 tahun 2015 pada pokok bahasan Aritmatika sosial.Penelitian ini menggunakan Penelitian Tindakan Kelas (PTK). Menurut TIM Pelatih Proyek PGSM. PTK adalah suatu bentuk kajian yang bersifat reflektif oleh pelaku tindakan yang dilakukan untuk meningkatkan kemantapan rasional dari tindakan mereka dalam melaksanakan tugas, memperdalam pemahaman terhadap tindakan - tindakan yang dilakukan itu, serta memperbaiki kondisi dimana praktek pembelajaran tersebut dilakukan.PTK adalah suatu bentuk kajian yang bersifat sistematis reflektif oleh pelaku tindakan untuk memperbaiki kondisi pembelajaran yang dilakukan. Adapun tujuan utama dari PTK adalah untuk memperbaiki/meningkatkan praktek pembelajaran secara kesenimbungan, sedangkan tujuan penyetaraan adalah menumbuhkan budaya meneliti di kalangan guru.Sesuai dengan jenis penelitian yang dipilih, yaitu penelitian tindakan maka penelitian ini menggunakan model pembelajaran Round Table, yaitu bentuk siklus yang satu ke siklus yang berikutnya. Setiap siklus meliputi palnning (rencana), action (tindakan), obsevation (pengamatan), dan reflection (refleksi. Langkah pada siklus berikutnya adalah perencanaan yang sudah direvisi, tindakan, pengamatan, dan refleksi. Sebelum masuk pada siklus 1 dilakukan tindakan pendahuluan yang berupa identifikasi permasalahan. Instrumen yang digunakan dalam penelitian ini adalah Silabus adalah seperangkat rencana dan pengaturan tentang kegiatan pembelajaran pengelolahan kelas, serta penilaian hasil belajar. RP/RPP adalah perangkat pembelajaran yang digunakan sebagai pedoman guru dalam mengajar dan disusun untuk setiap kali putaran. Masing masing RP berisi kompetensi dasar, indikator pencapaian hasil belajar, tujuan pembelajaran khusus, dan kegiatan belajar mengajar. Tes ini disusun berdasarkan tujuan pembelajaran yang akan dicapai. Digunakan untuk mengukur kemampuan pemahaman konsep matematika pada pokok bahasan aritmatika sosial. Tes formatif ini diberikan setiap akhir putaran. Bentuk soal yang diberikan adalah pilihan guru (objektif).

\section{Tekhnik Analisa Data}

Untuk mengetahui kefektivan suatu metode dalam kegiatan pembelajaran perlu diadakan analisa data. Pada penelitian ini menggunakan tekhnik analisa deskriptif kuantitatif, yaitu suatu metode penelitian yang bersifat menggambarkan kenyataan atau fakta sesuai dengan data yang diperoleh dengan tujuan untuk mengetahui hasil belajar yang dicapai peserta didik juga untuk memperoleh respon peserta didik terhdap kegiatan pembelajaran serta aktivitas peserta didik selama proses pembelajaran.Untuk menganalisis tingkat keberhasilan atau presentase keberhasilan peserta didik setelah proses belajar mengajar setiap putarannya dilakukan dengan cara memberikan evaluasi berupa soal tes tertulis pada akhir putaran.

Analisis ini dihitung dengan menggunakan statistik sederhana yaiu :

1. Untuk menilai ulangan atau tes formatif Peneliti melakukan penjumlahan nilai yang diperoleh peserta didik yang selanjutnya dibagi dengan jumlah peserta didik yang ada di kelas tersebut sehingga diperoleh rata - rata tes formatif dapat dirumuskan.

$$
\chi=\frac{\sum X}{\sum N}
$$

Dengan $: \chi=$ nilai rata - rata

$$
\begin{aligned}
& : \sum X=\text { jumlah semua nilai } \\
& \text { peserta didik } \\
& : \sum N=\text { jumlah peserta didik }
\end{aligned}
$$

\section{Untuk ketuntasan belajar}

Ada dua kategori ketuntasan belajar yaitu secara perorangan dan secara klasikal. Berdasarkan petunjuk pelaksanaan belajar mengajar, seorang peserta didik telah tuntas belajar bila telah mencapai skor $80 \%$ atau nilai 80. Dan kelas tersebut tuntas belajar bila di kelas tersebut terdapat $80 \%$ yang telah mencapai daya serap lebih dari atau sama dengan $80 \%$. Untuk menghitung presentase ketuntasan belajar digunakan rumus sebagai berikut : 


$$
\begin{aligned}
& \mathrm{P}=\frac{\sum \text { Peserta Didik yang tuntas belajar }}{\sum \text { Peserta Didik }} \mathrm{x} \\
& 100 \%
\end{aligned}
$$

\section{HASIL PENELTIAN DAN PEMBAHASAN}

Penelitian tindakan kelas dilaksanakan di kelas VII 8 SMP Negeri 10 Pekanbaru pada semester genap tahun ajaran 2014/2015 yang berjumlah 40 orang peserta didik, terdiri dari 15 siswa laki-laki dan 25 siswa perempuan. Penelitian dilaksanakan Peneliti Yulmaliza, S.Pd dan Yuli Asni, S.Pd. Dimana Yulmaliza, S.Pd sebagai pelaksana tindakan sedangkan Yuli Asni, S.Pd sebagai observer. Penelitian dilakukan sebanyak 3 siklus, setiap siklus terdiri dari 2 kali pertemuan dengan alokasi waktu setiap pertemuan adalah 3 x 45 menit dan diamati oleh observer yang melakukan observasi terhadap aktivitas siswa dan guru selama berlangsungnya proses pembelajaran dengan menggunakan lembar observasi. Penelitian bertujuan untuk meningkatkanaktivitas dan hasil belajar matematika peserta didik dengan menerapkan model pembelajaran Round Tablepada pokok bahasan aritmatika sosial. Data yang diperoleh dalam penelitian ini adalah hasil pengamatan aktivitas peserta didik dan guru setiap kali pertemuan dan nilai posttest yang diberikan setiap akhir siklus dalam bentuk objektif yang terdiri dari 10 soal dengan alokasi waktu 2 x 45 menit. Data yang diperoleh dalam penelitian ini merupakan data hasil penerapan model pembelajaran Round Table terhadap peserta didik selama proses pembelajaran berlangsung. Pelaksanaan kegiatan belajar mengajar untuk siklus 1 dilaksanakan pada tanggal 03 Februari 2015 di kelas VII 8 dengan jumlah peserta didik 40 orang. Dalam hal ini peneliti bertindak sebagai guru. Adapun proses belajar mengajar mengacu pada rencana pelajaran yang telah dipersiapkan. Pengamatan (observasi) dilaksanakan bersamaan dengan pelaksanaan belajar mengajar. Pada akhir proses belajar mengajar diberi tes formatif 1 dengan tujuan untuk mengetahui tingkat keberhasilan peserta didik dalam proses belajar mengajar yang telah dilakukan. Dari tabel diatas dapat dijelaskan bahwa dengan menerapkan model pemebelajaran Round Table diperoleh nilai rata - rata hasil belajar siswa adalah 81,85 dan ketuntasan belajar mencapai $72,50 \%$ atau ada 29 siswa dari 40 siswa yang sudah tuntas belajar. hasil tersebut menunjukkan bahwa pada siklus pertama secara klasikal siswa belum tuntas belajar, karena siswa yang memperoleh nilai $\geq 80$ hanya sebesar 81,85 . Pelaksanaan kegiatan belajar mengajar untuk siklus II dilaksanakan pada tanggal 17 Februari 2015 di kelas VII 8 dengan jumlah peserta didik sebanyak 40 orang. Dalam hal ini peneliti bertindak sebagai guru. Adapun proses belajar mengajar mengacu pada rencana pembelajaran dengan memperhatikan revisi pada siklus 1, sehingga kesalahan atau kekurangan pada siklus 1 tidak terulang lagi pada siklus II. Pengamatan (observasi) dilaksanakan bersamaan dengan pelaksanaan belajar mengajar. Pada akhir proses belajar mengajar, peserta didik diberi soal tes formatif II dengan tujuan untuk mengetahui tingkat keberhasilan peserta didik dalam proses belajar mengajar yang telah dilakukan. Instrumen yang digunakan adalah tes formatif II.Dari tabel diatas diperoleh nilai rata - rata hasil belajar siswa adalah 84,50 dan ketuntasan belajar mencapai $75,00 \%$ atau ada 30 orang siswa dari 40 siswa yang sudah tuntas belajar. hasil ini menunjukkan bahwa pada siklus II ini ketuntasan belajar secara klasikal telah mengalami peningkatan sedikit lebih baik dari siklus I. Adanyan peningkatan hasil belajar siswa ini karena siswa sudah mulai terbiasa dengan model pembelajaran Round Table yang diterapkan oleh guru. Pelaksanaan kegiatan belajar mengajar untuk siklus III dilaksanakan pada tanggal 10 Maret 2015 di kelas VII 8 dengan jumlah peserta didik 40 orang. Dalam hal ini peneliti bertindak sebagai guru. Adapun proses belajar mengajar mengacu pada rencana pembelajaran dengan memperhatikan revisi pada siklus II, sehingga kesalahan atau kekurangan pada siklus II tidak terulang lagi pada siklus III. Pengamatan (observasi) dilaksanakan dengan pelaksanaan belajar mengajar. Berdasarkan 
tabel diatas diperoleh nilai rata - rata tes formatif sebesar $87,43 \%$ dari 40 siswa yang telah tuntas belajar sebanyak 33 orang siswa dan 7 orang siswa belum mencapai ketuntasan belajar. maka secara klasikal ketuntasan belajar yang telah dicapai sebesar 82,50\% (termasuk kategori tuntas). Hasil pada siklus III ini mengalami peningkatan lebih baik adri siklus II. Adanya peningkatan hasil belajar pada siklus III ini dipengaruhi adanya peningkatan kemampuan siswa dalam mempelajari materi pelajaran yang telah diterapkan selama ini, adanya kerja semangat siswa yang dalam hal ini dapat bermain sambil belajar yang membuat siswa tersebut tidak bosan dalam melaksanakan proses belajar mengajar.

\section{PEMBAHASAN}

1. Ketuntasan Hasil Belajar Peserta Didik Melalui hasil penelitian ini menunjukkan bahwa penggunaan model pembelajaran Round Tablememiliki dampak positif dalam meningkatkan hasil belajar siswa. Hal ini dapat dilihat dari makin meningkatnya pemahaman siswa terhadap materi yang disampaikan guru (Ketuntasan belajar meningkat dari siklus I, siklus II dan siklus III) yaitu masing - masing 81,85\%,84,50\% dan $87,43 \%$. Pada siklus I ketuntasan belajar siswa secara klasikal telah tercapai.

2. Kemampuan Guru Dalam Mengelola Pembelajaran

Berdasarkan analisis data, diperoleh aktivitas peserta didik dalam proses pembelajaran dalam setiap siklus mengalami peningkatan. Hal ini berdampak positif terhadap hasil belajar peserta didik yang dapat ditunjukkan dengan meningkatnya nilai rata - rata peserta didik pada setiap siklus yang terus mengalami peningkatan.

\section{KESIMPULAN}

Berdasarkan hasil penelitian dan pembahasan dapat disimpulkan sebagai berikut :

1. Penerapan model pembelajaran Round Table dapat meningkatkan hasil belajar peserta didik. Dimana proses belajar mengajar dapat terlaksana dengan menyenangkan sehingga peserta didik dapat termotivasi untuk belajar.
2. Penerapan model pembelajaran Round Table dapat meningkatkan hasil belajar peserta didik dengan persentase pada siklus I sebesar $81,85 \%$, siklus II84,50 $\%$ dan siklus III $87,43 \%$.

\section{DAFTAR PUSTAKA}

Dimyati dan Mudjiono. 2010.Belajar dan Pembelajaran. Rineka Cipta. Jakarta. Depdiknas, 2004. Rambu-Rambu Penetapan Standar ketuntasan Belajar Minimum dan Analisis Hasil pencapaian Standar ketuntasan Belajar. Jakarta.

Djamarah, dan Zain., 2002, Strategi Belajar Mengajar, Rineka Cipta, Jakarta

Gulo, W., 2005, Strategi Belajar Mengajar, Grasindo, Jakarta

Ibrahim, Rahmadiarti, F., Nur, M., dan Ismono. 2000. Pembelajaran Kooperatif. Universitas Negeri Surabaya. Surabaya.

M. Saputra, Yudha., 2008 Strategi Pembelajaran Kooperatif Bandung: CV. Bintang Warli Artika

Oemar, Hamalik., 2007, Proses Belajar Mengajar, Bumi Aksara, Jakarta

Riduan dan Sunarto. 2003. Dasar- dasar Statistika. Alfabeta. Bandung.

Sanjaya. 2008. Strategi Pembelajaran Berorientasi Standar Proses Pendidikan. Kencana Prenada Media Group. Jakarta.

Sardiman, A. 2009. Interaksi dan Motivasi Belajar Mengajar. Raja Grafindo Persada. Jakarta.

Sholomo, sharan., 2009, Handbook Of Cooperative Learning, Imperium, Yogyakarta

Slameto. 2003. Belajar dan Faktor yang Mempengaruhinya. Rineka Cipta. Jakarta

Slavin, R. 2009.Cooperative Learning; Teori, Riset dan Praktik: Nusa Media. Bandung.

Sudjana. 2001. Dasar-Dasar Program Belajar Mengajar. Remaja Rosda Karya. Bandung 
Sudjana. 2005. Metoda Statistika. Tarsito. Bandung.

Trianto. 2010. Mendesain Model Pembelajaran Inovatif-Progresif: Konsep, Landasan dan Implementasinya pada Kurikulum Tingkat Satuan Pendidikan.Kencana. Jakarta. 
